\title{
Phytochemical Prospecting, Antimicrobial Activity, and Acute Toxicity of Aqueous Plant Extract of Two Plant Species Allophylus edulis (A. St. Hilaire, Cambessedes \& A. Jussieu) RADLK ex WARM and Matayba elaeagnoides RADLK
}

\author{
Gisele Arruda, Lhuanna Gabriela Vardânega Périco, Rosimeri Parpinelli, Rafael Franco Peretti, \\ Mayara Camila Scur, Franciele Aní Caovilla Follador
}

\begin{abstract}
This study represents one of the earliest studies reporting biological properties (antimicrobial activity, acute toxicity, and phytochemical prospecting) of the aqueous extract of leaves of two plant species, Matayba elaeagnoides Radlk, and Allophylus edulis (A. St. Hilaire, Cambessedes \& A. Jussieu) Radlk. ex Warm, both belonging to the Sapindaceae family. Phytochemical prospecting detected the presence of saponins and flavonoids in both species. The acute toxicity test with Artemia salina showed toxicity rates with $\mathrm{LC} 50 \%$ of $100 \mathrm{mg} / \mathrm{mL}$ for Matayba elaeagnoides. Interestingly, none of the extracts showed microbiological activity, using the diffusion disc method against Staphilococus aureus, Escherichia coli and Candida albicans.
\end{abstract}

Index Terms - Medicinal plants, Phytochemical screening, Plant biological properties, Toxic level.

\section{INTRODUCTION}

Brazil has a great vegetal biodiversity, which can be considered the largest in the world, representing potential source of important substances that can present bioactivities, among them the antimicrobial, widely researched due to the appearance of strains of multi-resistant microorganisms, resulting from the irrational use of syntethic antimicrobials.

Medicinal plants have been used by man for a long time, mainly for the treatment or prevention of diseases [1]. After the discovery of the pharmacological potential of plants, products of natural origin have been extensively researched, contributing significantly to the discovery of new substances with important applications in medicine, helping in new pharmacological discoveries [2]. Among the biological activities that plants can present, antimicrobials stand out due to the fact that they are the class of drugs most used in

Gisele Arruda, Department of Health Sciences, State University of Western Paraná, Francisco Beltrão, Brasil

Lhuanna Gabriela Vardânega Périco, Department of Biology, University of Paranaense, Francisco Beltrão, Brasil

Rosimeri Parpinelli, Department of Biology, University of Paranaense, Francisco Beltrão, Brasil

Rafael Franco Peretti, Department of Biology, University of Paranaense, Francisco Beltrão, Brasil

Mayara Camila Scur, Department of Biology, University of Paranaense, Francisco Beltrão, Brasil

Franciele Aní Caovilla Follador, Department of Health Sciences, State University of Western Paraná, Francisco Beltrão, Brasil hospitals and in the community. Because it is frequently used, its inadequate use can lead to problems such as bacterial resistance, elevated costs, morbidity, and mortality [3].

Natural products have been used in the treatment of diseases for thousands of years [4]. This popular knowledge along with scientific development has led to great advances in the therapeutic study of medicinal plants, discovering substances with promising biological and pharmacological activities [5]. Although the use of plants as a curative medium is a highly widespread and popular activity, often the use of plants with medicinal properties is misused, since many plants have toxic principles and their indiscriminate use can cause serious problems. Thus, the importance of toxicity studies of these plants is clarified in order to report their real pharmacological potential .

Studies on the phytochemical compositions of medicinal plant bioactivities have caused great interest, since there is a need for the discovery of new substances, especially those that present antimicrobial activity and that do not present damages to humans. Secondary metabolites are substances that are not essential to all plants as the primary metabolites, but they play an important role in the relationship between the plant and the environment, such as protection against herbivory, pathogen attack, competition between plants, and attraction of beneficial organisms such as pollinators, seed dispersers, and symbiotic microorganisms [6].

The genus Matayba presents few studies about its species. In this way, Matayba elaeagnoides was selected for this study. This plant is popularly known as "Miguel-pintado, camboatã, camboatá". In popular usage, this plant stands out mainly for its anti-inflammatory, analgesic, and anticancer activity [7]. Although this species is used for different purposes in folk medicine, its bioactivity has not been scientifically proven.

The Allophylus edulis belongs to the Sapindaceae familys and it's popularly known as "Vacum", which is a native Brazilian plant [8]. The tea of its leaves and its fruits are popularly used for the treatment of dysenteries, fever, and diabetes [9].

Considering the importance in determining the antimicrobial activity of plant extracts for new sources of active principles for the production of phytotherapics due to the increase of the microbial resistance, besides the important role of knowing if there is level of toxicity and the main 
Phytochemical Prospecting, Antimicrobial Activity, and Acute Toxicity of Aqueous Plant Extract of Two Plant Species Allophylus edulis (A. St. Hilaire, Cambessedes \& A. Jussieu) RADLK ex WARM and Matayba elaeagnoides RADLK

secondary metabolites, the objective of the work was to evaluate the antimicrobial activity, to carry out the phytochemical prospection, and to determine the acute toxicity of the aqueous extract of two species of plants, Matayba elaeagnoides and Allophylus edulis.

\section{MATERIALS AND MethodS}

\section{A. Preparation of the Extract}

The leaves of Allophylus edulis and Matayba elaesgnoides were collected systematically in an area of the Brother Cirilo Environmental Park, located in Francisco Beltrão, Paraná, in February 2017 (coordinates: 2602'50 "S and 5302'22" W). The botanical identity of the plants was confirmed by Biologist Luciana Pelizzaro. The leaves of each plant were dried in an oven $\left(40^{\circ} \mathrm{C}, 48 \mathrm{~h}\right)$ and ground in a knife mill. Leaf powder infusion was prepared using $20 \mathrm{~g}$ in $1 \mathrm{~L}$ distilled water, left on a rotary shaker at $220 \mathrm{xg}$ for $24 \mathrm{~h}$. The material was then filtered on Whatman filter paper. The extract of the two plants was stored in a concentration of $200 \mathrm{mg} / \mathrm{mL}$ at $4^{\circ} \mathrm{C}$ until use [10].

\section{B. Phytochemical Prospecting}

The phytochemical prospection of the main types of secondary metabolites was made using a classical qualitative methodology recommended by [11] with some adaptations. The presence of the classes of compounds pyrogallic tannins, alkaloids, coumarins, saponins, anthocyanins, flavonoids, triterpenoids, and steroids were evaluated.

\section{Evaluation of antimicrobial activity}

For the evaluation of the antimicrobial activity of the aqueous extract of Allophylus edulis and Matayba elaeagnoides against Escherichia coli, Staphylococcus aureus, and yeast Candida albicans, the determinations of the Manual Clinical and Laboratory Standards Institute [10] with adjustments were used. For the test, $6 \mathrm{~mm}$ diameter sterile filter paper disks received aliquots of $20 \mu \mathrm{L}$ of the aqueous extract of the plants in four concentrations $(200 \mathrm{mg} / \mathrm{mL}$, $100 \mathrm{mg} / \mathrm{mL}, 50 \mathrm{mg} / \mathrm{mL}, 12.5 \mathrm{mg} / \mathrm{mL}$ ) in petri plates containing Mueller-Hinton agar in which a pure colony of the tested microorganisms and two control discs containing the antibiotic streptomycin and fluconazole were previously inoculated. After 24 hours the inhibition halos were measured and considered with inhibitory activity those that had diameters greater than $6 \mathrm{~mm}$.

\section{Assessment of Acute Toxicity}

The acute toxicity test was carried out by using the methodology proposed by [12] with adaptations. Artemia saline cysts were placed in $35 \%$ saline solution, with a $40 \mathrm{~W}$ lamp and an aeration pump connected for a period of 24-48 hours until their hatching. The aqueous extract was prepared in $35 \%$ saline solution and tested at concentrations of $200 \mathrm{mg} / \mathrm{mL}, 100 \mathrm{mg} / \mathrm{mL}$, and $50 \mathrm{mg} / \mathrm{mL}$. Five test tubes were incubated with 10 Artemia salina/tube. After 24 hours exposure the LC50\% was determined.

\section{RESUlTS AND DisCUSSION}

The results of the antimicrobial activity of the aqueous extract of Matayba elaeagnoides tested at concentrations of
$100 \%, 50 \%, 25 \%$, and $12.5 \%$, and of the extract of Allophylus edulis at concentrations of $100 \%, 50 \%$, and $25 \%$ against Escherichia coli, Staphylococcus aureus, and Candida albicans showed that inhibition halos could not be observed at any of the concentrations against the three microorganisms tested, that is, they did not present antimicrobial activity.

In a study conducted by [13] with ethanolic extract of the leaves of Dilodendron bipinnatum - plant belonging to the same family of plants tested in this study - it was observed that the extract did not present antimicrobial activity against Escherichia coli and Staphylococcus aureus, what validates the present study, although it presented activity against Candida albicans in concentration above $250 \mathrm{mg} / \mathrm{mL}$. In this respect, it should be noted that the concentration that the authors used to test the extract against the latter microorganism was 1.5 times higher than those tested in this study. The authors of this study justified the absence of antimicrobial activity due to the fact that plant extracts present complex compositions, where bioactive substances can be present in small concentrations, not exerting significant activity, being able to attribute this same fact to the absence of activity found in the present study although confirmed to the presence of saponins and terpenoids.

With the essential oil of Allophylus edulis, in a study developed by [14], it was reported that it did not present antimicrobial activity against Gram-negative, Gram-positive bacteria, and yeast strains, what validates the present study.

No information was found in the literature regarding the antimicrobial effect of Matayba elaeagnoides leaf extracts, only about extracts of their barks, seeds and fruits [15], which showed activity against Staphylococcus aureus and inactivity against Candida albicans and Escherichia coli in the latter case, confirming the data of the present study.

The results of the acute toxicity test show that the aqueous extract of Matayba elaeagnoides presents high toxicity, with high mortality in concentrations above $100 \mathrm{mg} / \mathrm{mL}$ of the extract against larvae of Artemia salina, that is, LC50\% was $100 \mathrm{mg} / \mathrm{mL}$. The extract of Allophylus edulis presented low toxicity.

No studies were found on Matayba elaeagnoides that reveal its toxicity on Artemia salina, only with its bark, which had its chemical constituents isolated to relate to possible pharmacological and biological activities [15].

Similar results for the toxicity of Allophylus edulis were found by [16] where the raw aqueous extract and the extract diluted in different concentrations of the fruits of the plant were not toxic to Artemia salina in the concentration of $25 \%$ of the extract, concluding that the species does not present substances with cytotoxic characteristics.

The authors noted that the good toxicity result of this extract may mean that the extract is not in sufficient concentration to present some level of toxicity, and that this fact possibly means that the extract in this concentration would be tolerated in a biological system without presenting some kind of evil effect. Despite the good results, the authors suggest further studies [16].

The experiments carried out for the characterization and phytochemical screening of the aqueous extract of Allophylus edulis revealed the presence of the classes of the metabolites saponins and flavonoids. In a study by [14], 43 compounds representing $82 \%$ of the essential oil composition of Allophylus edulis were identified. The predominant 
compounds were sesquiterpenes $(74.88 \%)$, where $42.9 \%$ were hydrocarbon derivatives and $31.98 \%$ oxygenates; however small concentrations of monoterpenes $(0.51 \%)$ and diterpenes $(6,6 \%)$ were identified.

The tests conducted for the characterization and phytochemical evaluation of the aqueous extract of Matayba elaeagnoides revealed the presence of classes of the secondary metabolites: saponins and flavonoids. In relation to the biological potential attributed to the classes of metabolites found in the present study, it is known that the medicinal use of plants containing flavonoids is widely spread and, although some studies have shown that certain flavonoids may have a mutagenic effect, they are generally considered beneficial and are used for their antitumor, antiviral, anti-hemorrhagic, hormonal, anti-inflammatory, antimicrobial and antioxidant properties [11].

Flavonoids represent one of the most important phenolic groups of products of natural origin and are much diversified, as they are found in fruits, vegetables, seeds, tree barks, roots, stalks, and flowers. This compound presents several biological activities, among them are antitumor activity, antioxidant, antiviral and anti-inflammatory, which explains the popular use in products such as teas [17], and also the use in the formulation of herbal medicines for the treatment or prevention of certain diseases [18].

The saponins are chemical compounds that have biological activities such as anti-yeasts and antibacterial, acting on the sterols of the plasma membrane of microorganisms through denaturation of proteins [19]. In addition, the saponins constitute a large group of sterol glycosides or polycyclic terpenes which have antifungal, antiviral, spermicidal, expectorant, diuretic, anti-inflammatory, immunomodulatory and cytoprotective activity. Most are used in industry, with use in the contraceptives production [20].

According to [21], phytochemical analyzes are of great help in the study of pharmacognosy, in the search for active principles and identification of the bioactive compounds of plants or animals, considering that these can vary in their composition and quantity due to environmental factors.

Although the phytochemical analysis showed the presence of saponins that have antimicrobial activity, the microbiological studies showed no effect against Staphylococcus aureus, Escherichia coli, and Candida albicans; therefore it is suggested that the concentrations tested may have been low and not enough for antimicrobial activity; however they were sufficient to demonstrate a certain level of acute toxicity. Further studies may show better effects of the extract of these plants, revealing its biological effects in a better way.

\section{CONCLUSION}

The aqueous extract of Matayba elaeagnoides and Allophylus edulis did not present antimicrobial activity against Staphilococus aureus, Escherichia coli, and Candida albicans, although the phytochemical prospection revealed the presence of flavonoids and saponins. As for the toxicity test carried out with Artemia salina, Matayba elaeagnoides presented LC50\% 100mg/mL, and Allophylus edulis showed no toxicity. In this way further tests with more concentrations of the extracts with these two species may better show their biological effects.

\section{REFERENCES}

[1] C. Costa, D. Teixeira. (2019, February). Using nature as a model: frow Willow to Aspirin. Usando a natureza como modelo: do Salgueiro à Aspirina, University of Évora: Department of Chemistry. Journal of the University of Evora. [Online]. Available: https://www.ueline.uevora.pt/Canais/dossier/(item)/27

[2] M. T. Souza, et al., "Phytochemical and antinociceptive properties of Matayba elaegnoides Radlk Barks," Journal of Biosciences, Zeitschrift für Naturforschung, vol. 62, Jun. 2007, pp. 550-554.

[3] Brasil. (2019, February). Anvisa. National Health Surveillance Agency. Agência Nacional de Vigilância Sanitária. "Reference Service: Antimicrobials: Theoretical basis and clinical use: General Concepts," "Serviço de Referência: Antimicrobianos: Bases teóricas e uso clínico," Available: http://www.anvisa.gov.br/servicosaude/controle/rede_rm/cursos/rm_c ontrole/opas_web/modulo1/conceitos.htm

[4] A. Harvey, "Strategies for discovering drugs from previously unexplored natural products," Drug Discovery Today, vol. 5, Jul. 2000, pp. 294-300.

[5] D. J. Newman, "Natural products as leads to potential drugs: an old process or the new hope for drug discovery?," Journal of Medicinal Chemistry, vol.51, Abr. 2008, pp. 2598 - 2599.

[6] L. E. P. Peres. (2019, February). Secondary Metabolism. Metabolismo Secundário. Available: http://www2.ufpel.edu.br/biotecnologia/gbiotec/site/content/paginado professor/uploadsprofessor/ce5449dfcf0e02f741a5af86c3c5ae9a.pdf? PHPSESSID=e32d8df36f08f86ef80010a253f33762

[7] M. L. Mesquita, et al., "New ether glycosides from Matayba guianensis with antiplasmodial activity,” Bioog. Med. Chem, vol. 13, Jul. 2005, pp.4499-506.

[8] H. Lorenzi, "Brazilian Trees: Manual of Indentification and Cultivation of Native Arboreal Plants of Brazil," “Árvores Brasileiras: Manual de Identificação e Cultivo de Plantas Arbóreas Nativas do Brasil," 4 ed. vol. 1, São Paulo: Nova Odessa, 2002, pp. 23-24.

[9] L. J. Franco, V. L. Fontana, "Ervas \& plantas: a medicina dos simples," 6. ed. vol 1. Erexim: Edelbra, 2001, pp. 183-184.

[10] L. D. Weber, et al., "Chemical composition and antimicrobial and antioxidant activity of essential oil and various plant extracts from Prunus myrtifolia," African Journal of Agricultural Research, vol. 9, Jan. 2014, pp. 846-853.

[11] C. M. O. Simões, et al., Pharmacognosy: From Plant to Drug, Farmacognosia: da Planta ao Medicamento, 5. ed. Porto Alegre: RS. 2005, pp. 127-129.

[12] B. N. Mayer, et al., "Brine shrimp: A convenient general bioassay for active plant constituents," Journal of Medical Plant Research, vol. 45, May. 1982, pp. 31-34.

[13] J. C. Santos, C. A. N. Oliveira, L. Varella, A. P. Matos, "Chemical constituents and antimicrobial of extract of Dilodendron bipinnatum (Sapindaceae)," "Constituintes químicos e atividade antimicrobiana dos extratos de Dilodendron bipinnatum (Sapindaceae)," Química nova, vol. 33, Out. 2010, pp. 2080-2082.

[14] W. A. Ribeiro Filho, et al. (2019, February). "Evaluation of the cytotoxic potential and chemical composition of the essential oil of Allophylus edulis (Sapindaceae) and evaluation of the antimicrobial potential," "Avaliação do potencial citotóxico e composição química do óleo essencial de Allophylus edulis (Sapindaceae) e avaliação do potencial antimicrobiano," in $36^{\mathrm{a}}$ Reunião Anual da Sociedade Brasileira de química. 2013. Avilable: http://sec.sbq.org.br/eventos/36ra/resumos/T1652-1.pdf

[15] M. T. Souza, "Phytochemical studyand evaluation of tha biological activity of Matayba elaeagnoides Radlk," "Estudo fitoquímico e avaliação da atividade biológica de Matayba elaeagnoides Radlk," 2006. Dissertação (Mestrado em Ciências Farmacêuticas) Universidade do Vale do Itajaí, Itajaí, 2006.

[16] S. H. Umeo, T. M. Ito, M. E. Yokota, M. B. Romagnolo, and A. Laverde Junior, "Evaluation of antioxidante, anticholinesterase and cytotoxic properties of fruits of Allophylus edulis (A.St.-Hil.,cambes. \& A. Juss.) Radlk. (Sapindaceae)," “Avaliação das propriedades antioxidantes, anticolinesterásicas e citotóxicas dos frutos de 
Phytochemical Prospecting, Antimicrobial Activity, and Acute Toxicity of Aqueous Plant Extract of Two Plant Species Allophylus edulis (A. St. Hilaire, Cambessedes \& A. Jussieu) RADLK ex WARM and Matayba elaeagnoides

RADLK

Allophylus edulis (A.St.-Hil.,cambes. \& A. Juss.) Radlk. (Sapindaceae)," Arq. Ciênc. Saúde UNIPAR, vol.15, May. 2011, pp. 167-171.

[17] M. A. S. Coutinho, M. F. Muzitano, and S. S. Costa, "Flavonoids: Potential therapeutic agentes for the inflammatory process," "Flavonóides: Potenciais agentes terapêuticos para o processo inflamatório," Revista Virtual De Química, vol. 1, Jul. 2009, pp. 241-256.

[18] F. A. Cerqueira, K. Z. Fonseca, R. L. Silva, L. L. Santos, and F. Silva, "Flavonóides em medicamentos fitoterápicos comercializados em Santo Antônio de Jesus, Recôncavo da Bahia," Enciclopédia Biosfera: Centro Científico Conhecer, vol. 7, Out. 2011, p. 1443- 1450.

[19] G. F. Killeen, et al., "Antimicrobial saponins of Yucca schidigera and the implications of their in vitro properties for their in vivo impact," $J$. Agr. Food Chem. vol. 46, Jul. 1998, pp.3178-3186.

[20] P. R. S. Ribeiro. (2019, February). "Saponinas". Graduação em Farmácia - 2008 - Faculdade de Imperatriz. Available: http://farmaciafacimp.xpg.uol.com.br/saponinas.pdf

[21] D. M. Oliveira, V. A. Royo, M. O. Mercadantes-Simões, "Qualitative photochemical analysis of the roots of de Magonia pubescens (Sapindaceae) occuring in Montes Claros-MG," "Análise fotoquímica qualitativa das raízes de Magonia pubescens (Sapindaceae) ocorrente em Montes Claros-MG,", in $64^{\circ}$ Congresso Nacional de Botânica. Belo Horizonte. $\quad$ pp.10-5., 11., 2013. Available: http://www.botanica.org.br/trabalhos-cientificos/64CNBot/resumo-ins 18105-id5163.pdf

Gisele Arruda is Teacher at the State University of Western Paraná. He has a Master's Degree in Biochemical Sciences and a PhD in Comparative Biology. Has several publications in this area. Coordinator of the research project with mutagens, genetics and cancer.

Lhuanna Gabriela Vardânega Périco is a recently graduated Biologist, participant in this project and several others in the area. Has publications in several events.

Rosimeri Parpinelli is a recently graduated Biologist, participant in this project and several others in the area. Has publications in several events

Rafael Franco Perreti is a recently graduated Biologist, participant in this project and several others in the area. Has publications in several events.

Mayara Camila Scur is a PhD in Ecology and Conservation, has several publications and during the summers of 2016 and 2017, the researcher had the opportunity to total four months of experience in the Antarctic environment, through participation in Brazilian Antarctic Operations XXXIV and XXXV.

Franciele Aní Caovilla Follador is a Teacher and $\mathrm{PhD}$ at 17 years of the State University of Western Paraná. Director of the Health Sciences Center. Has several publications in this area. 